\title{
Land Use Cover Types and Forest Management Options for Carbon in Mabira Central Forest Reserve
}

\author{
Aisha Jjagwe, Vincent Kakembo, and Barasa Bernard
}

\section{Contents}

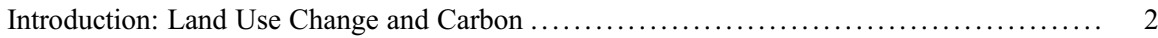

Mabira Central Forest Reserve: Location and Management $\ldots \ldots \ldots \ldots \ldots \ldots \ldots \ldots \ldots \ldots \ldots, \quad 3$

Estimating Biomass and Soil Organic Carbon Stocks in Mabira CFR .................. 5

Estimating Above-Ground Biomass and Carbon Stocks ......................... 5

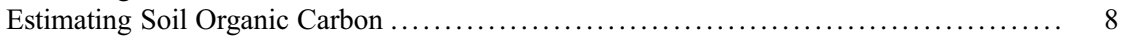

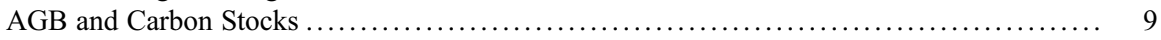

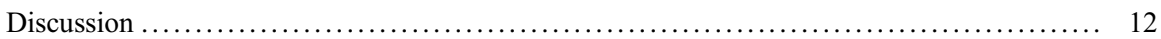

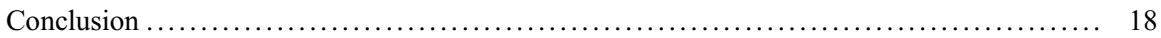

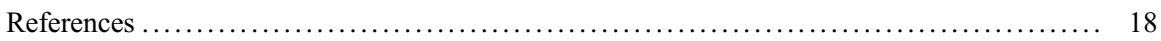

\section{Abstract}

Mabira Central Forest Reserve (CFR), one of the biggest forest reserves in Uganda, has increasingly undergone encroachments and deforestation. This chapter presents the implications of a range of forest management options for carbon stocks in the Mabira CFR. The effects of forest management options were reviewed by comparing above-ground biomass (AGB), carbon, and soil organic carbon (SOC) in three management zones. The chapter attempts to provide estimates of AGB and carbon stocks ( $\mathrm{t} / \mathrm{ha}$ ) of forest (trees) and SOC using

This chapter was previously published non-open access with exclusive rights reserved by the Publisher. It has been changed retrospectively to open access under a CC BY 4.0 license and the copyright holder is "The Author(s)". For further details, please see the license information at the end of the chapter.

\footnotetext{
A. Jjagwe $(\bowtie) \cdot$ V. Kakembo

Department of Geoscience, Nelson Mandela University, Port Elizabeth, South Africa e-mail: aishajagwea@hotmail.com; vincent.kakembo@mandela.ac.za

B. Bernard Institute of Environment and Natural Resources, Makerere University, Kampala, Uganda e-mail: barasagis@gmail.com
} 
sampling techniques and allometric equations. AGB and carbon were obtained from a count of 143 trees, measuring parameters of diameter at breast height $(\mathrm{DBH})$, crown diameter $(\mathrm{CW})$, and height $(\mathrm{H})$ with tree coordinates. It also makes use of the Velle (Estimation of standing stock of woody biomass in areas where little or no baseline data are available. A study based on field measurements in Uganda. Norges Landbrukshoegskole, Ås, 1995) allometric equations developed for Uganda to estimate AGB.

The strict nature reserve management zone was noted to sink the highest volume of carbon of approximately 6,771,092.34 tonnes, as compared to the recreation zone $(2,196,467.59$ tonnes) and production zone (458,903.57 tonnes). A statistically significant relationship was identified between AGB and carbon. SOC varied with soil depth, with the soil surface of $0-10 \mathrm{~cm}$ depth registering the highest mean of $2.78 \%$ across all the management zones. Soil depth and land use/ cover types also had a statistically significant effect on the percentage of SOC $(P=0.05)$. A statistically significant difference at the $95 \%$ significance level was also identified between the mean carbon stocks from one level of management zones to another. Recommendations include: demarcating forest boundaries to minimize encroachment, enforcement of forestry policy for sustainable development, promote reforestation, and increase human resources for efficient monitoring of the forest compartments.

\section{Keywords}

Above-ground biomass · Allometric equations · Soil organic carbon · Land use/ cover change

\section{Introduction: Land Use Change and Carbon}

Representing 33\% of the global land area (FAO 2011) and containing more carbon per unit area than any other land cover type (Hairiah et al. 2011), forests comprise the biggest percentage of biomass and play a big role in mitigating greenhouse gas emissions, especially carbon dioxide. According to the FAO (2010), biomass is the organic matter both above and below the ground. Forest biomass assessment is very important for national development planning, as well as scientific studies of ecosystem productivity and carbon budgets (Parresol 1999; Zheng et al. 2004). Considering climate change trends, there is a growing need for information on forest carbon stocks. Olson et al. (1983), Thornes (2002), and Schimel et al. (2001) point out that forests contain nearly $85 \%$ of the global above-ground carbon, and $40 \%$ of the below-ground terrestrial carbon stocks (Brown and Lugo 1984; Dixon et al. 1994). Land use/cover change (LUCC) has led to destruction of habitats, forests, exposed land to erosion, and affected human well-being (Foley et al. 2005; Kerr et al. 2007; Ellis and Pontius 2007; Arsanjani 2012). Alterations caused by LUCC account for the release of greenhouse gases into the atmosphere, resulting into global warming. Further effects are manifest in climate variability and change (Hashim and Hashim 2016). Studies by Watson et al. (2000), UNEP (2002), and Lambin and Geist (2008) 
have cautioned about instant and threatening effects of LUCC on agriculture, biodiversity, human health, and well-being. Despite its importance, accurate statistics on LUCC are not available in tropical countries (Ochoa-Gaona and Gonzalez-Espinosa 2000). Agriculture is still the most significant driver of global deforestation. Given the importance to the planet's future of both agriculture and forests, there is an urgent need to promote positive interactions between these two land uses (FAO 2016).

The rate of deforestation, estimated at $0.4-0.7 \%$ per year (Shrestha et al. 2004; Parry et al. 2007), constitutes immense environmental stress. Between 2000 and 2010, 13 million ha of world forest were lost (FAO 2010), implying an increase in the amount of carbon dioxide into the atmosphere. According to Baccini et al. (2012) and Harris et al. (2012), deforestation and forest degradation contribute about 20\% of the greenhouse emissions. Land use change leads to alterations in carbon storage in soils and vegetation. Consequently, it strongly influences emissions and fixation of carbon in these ecosystems (Jandl et al. 2007). Jjagwe et al. (2017) identify the significant drivers of land use/cover changes in and around the Mabira CFR as: high household size, loss of soil fertility, poor agricultural practices, establishment of roadside markets, industrialization, and the unclear CFR boundary. Against the above background, that the main aim here is to estimate and compare total tree biomass and carbon stocks among the three management zones of the Mabira CFR.

\section{Mabira Central Forest Reserve: Location and Management}

Mabira Central Forest Reserve (CFR) is currently the largest natural rainforest region found in the Lake Victoria crescent of Uganda, spanning the districts of Mukono, Buikwe, and Kayunga (Fig. 1). It lies 54 east and $26 \mathrm{~km}$ west of the cities of Kampala and Jinja, respectively. It covers about 26,250 ha and is situated between $3252^{\circ}-3307^{\circ} \mathrm{E}$ and $024^{\circ}-035^{\circ} \mathrm{N}$, at an altitude of $1070-1340 \mathrm{~m}$ above sea level. The topography is characterized by gently undulating plains that have numerous flat topped hills and wide shadow valleys. Temperatures are fairly constant throughout the year, with an average of $26^{\circ} \mathrm{C}$. It has two peak rain seasons between March-May and September-November. Rainfall ranges between 1250 and $1400 \mathrm{~mm}$ per annum.

The forest is globally recognized as an important conservation biome rich in biodiversity, with over 300 bird species (Lepp et al. 2011) and 365 plant species (Howard and Davenport 1996). Currently, the forest has 27 enclaves; considering its proximity to Kampala city, the area has attractions for commercial utilization. Uganda's population growth rate of $3.2 \%$, as per the 2002 population census (UBOS 2010), is one of the highest globally.

Mabira CFR was gazetted as a CFR in the 1900 under the Buganda agreement. It has been protected as a Forest Reserve since 1932 and is currently managed by the National Forest Authority (NFA). Forest management is under three main zones, namely: the strict nature reserve where no extraction is permitted except for research activities; the recreation buffer zone where activities like ecotourism and limited harvesting are permitted; and the production zone which accommodates agriculture, livestock grazing, legal and unregulated harvesting of timber. The forest has 


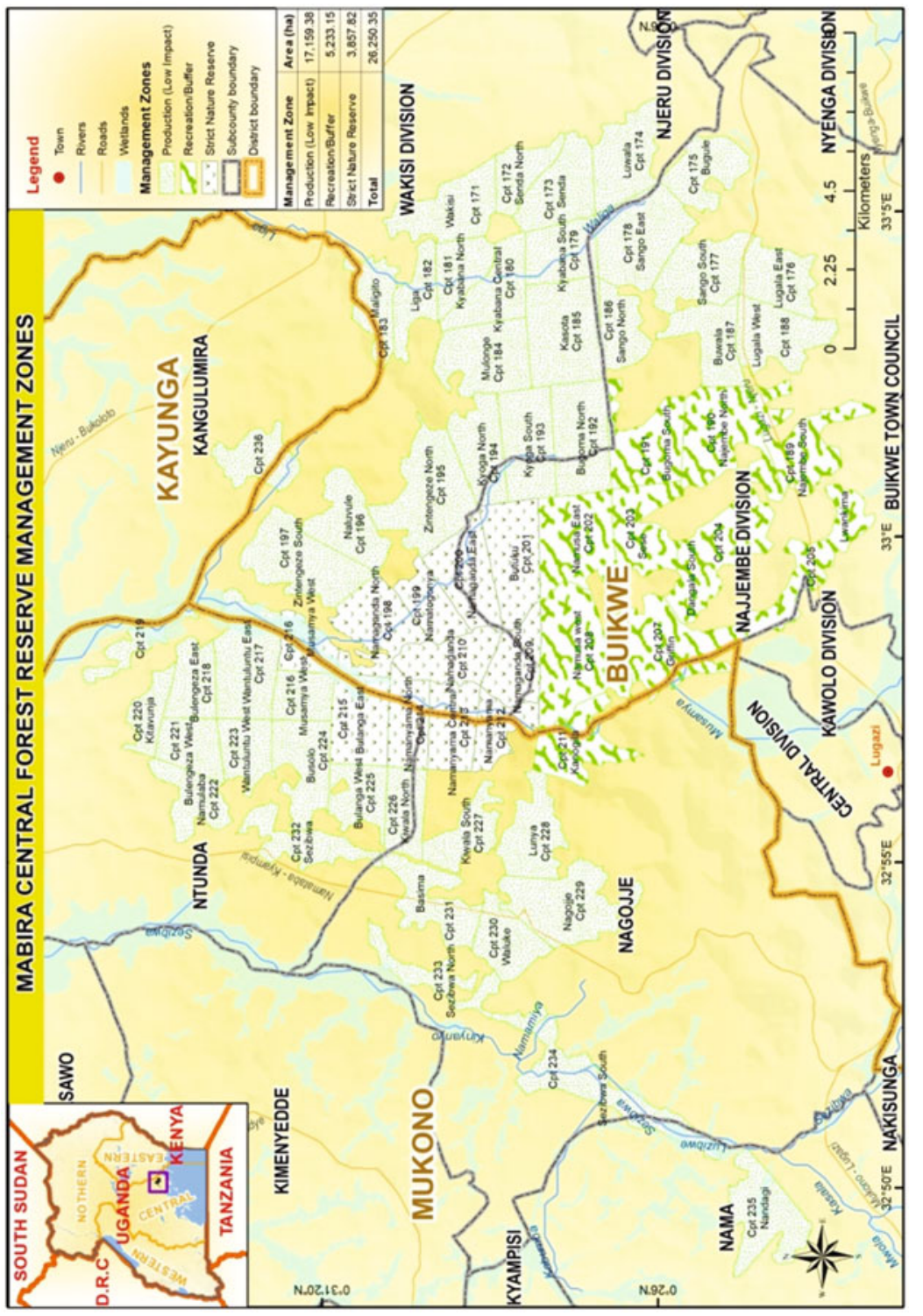

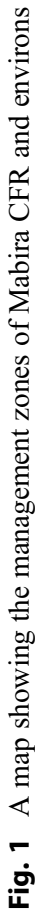


undergone dramatic changes, especially since the early 1970s, in the form of encroachments and deforestation. These activities resulted from the desire by the government of the time to expand agriculture and permit free settlement anywhere. This forest region is estimated to have quite a high population density, with some places having an average of up to 15,122 people/sq. km in Parishes like Nakazadde (Schwarz and Fakultät für Geomatik, Hochschule Karlsruhe-Technik und Wirtschaft 2010) and an average of seven members per household. Over $80 \%$ of the population is heavily dependent on the forest ecosystem for their livelihood (Bush et al. 2004) in form of agriculture, lumbering, and brick laying. Studies by NFA (2009) indicate that population pressure coupled with high levels of poverty continue to constrain the remaining forest cover by way of conversion to other land uses. The high resistance over the proposal by government in 2007 to convert 7186 ha of forest to sugar production by the Sugar Corporation of Uganda Limited (SCOUL) is a case in point.

As a means to improve management in the forest reserve, several mechanisms have been devised in the revised forest management plan (MWE 2017), which include but not limited to: yield control and harvest, Collaborative Forest Management (CFM), licenses, silviculture, and rehabilitating encroachments. Despite the few success stories where CFM has been adopted, it is noteworthy that in the many communities where CFM agreements are implemented, no tangible economic benefits have been realized (Turyahabwe et al. 2012).

\section{Estimating Biomass and Soil Organic Carbon Stocks in Mabira CFR}

\section{Estimating Above-Ground Biomass and Carbon Stocks}

In order to determine the above-ground biomass (AGB) stocks, living biomass was considered. Studies by Djomo et al. (2010) and Brown (2002) have identified challenges of using the direct/destructive approach to estimate biomass. Consequently, we applied the indirect approach to estimate biomass content. The approach is not time consuming, cheap, and nondestructive, as borne out in studies by Tackenberg (2007), Chen et al. (2009), and Henry et al. (2011). The use of generalized allometric equations is proven and reliable in estimating AGB and carbon stocks and a number of them have been developed for different purposes, species, and regions.

More than $95 \%$ of the variation in AGB is explained by diameter at breast height (DBH) alone (Brown 2002). Studies by Djomo et al. (2010, 2016) and Ngomanda et al. (2014) show that the input of tree height improves the quality of AGB estimation. Biomass equations have been preferred, if a representative sample of tree-wise data is acquired (Brown 1997; Basuki et al. 2009; Djomo et al. 2010; Beets et al. 2012; Chave et al. 2014; Ngomanda et al. 2014; Mokria et al. 2015).

A team of eight people was employed in this process to survey management zones and take tree measurements. An NFA official with a security guard per management zone led the team in this exercise. Three management zones were 
Table 1 Sampled compartments

\begin{tabular}{l|l|c}
\hline Management zone & Name and compartment number & Number of trees \\
\hline \multirow{2}{*}{ Strict nature reserve } & Compartment 209 & 63 \\
\cline { 2 - 3 } & Compartment 212 & \\
\hline Recreation/buffer zone & Compartment 208 & 50 \\
\hline Production zone & Compartment 211 & 30 \\
\hline Total number of trees samples & $\mathbf{1 4 3}$ \\
\hline
\end{tabular}
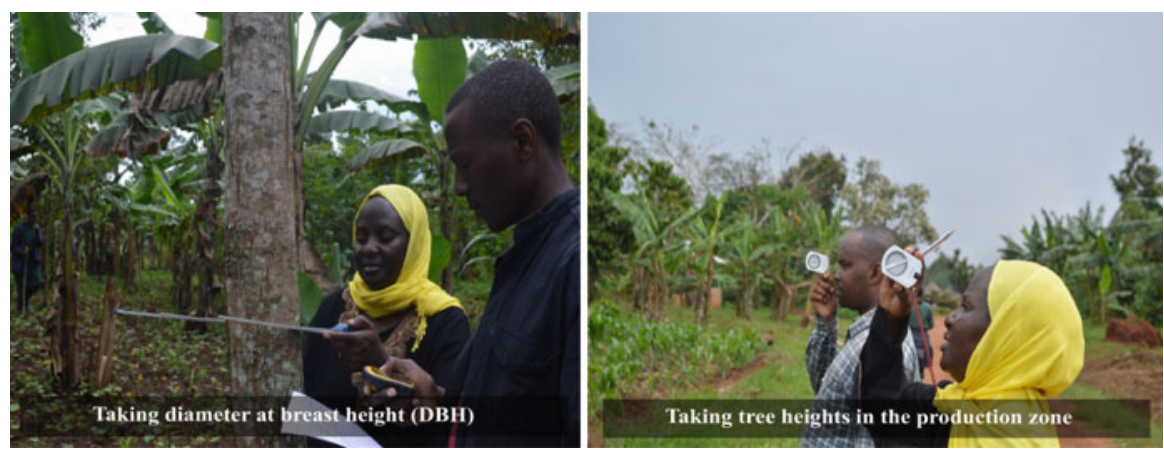

Fig. 2 Measurements for tree parameters

surveyed, each representing unique but homogeneous blocks. From the three zones, four compartments were considered as summarized in Table 1.

Resource utilization and management in the respective zones varies. Under the strict nature reserve, no extraction is permitted except for research activities, undertaken under very restrictive measures. Whereas the recreation buffer zone permits activities like ecotourism and limited harvesting, the production zone accommodates agriculture, livestock grazing, legal and unregulated harvesting of timber.

Field sites were randomly selected, taking 20 square plots of $30 \mathrm{~m} \times 30 \mathrm{~m}$ from the strict nature reserve, where 63 trees were sampled. The same number of square plots of $50 \mathrm{~m} \times 50 \mathrm{~m}$ was considered from the recreation/buffer and production zones, where measurements of 50 and 30 trees were taken, respectively. The plot sizes varied, considering variations in tree densities and sampling intensity. Consequently, bigger plot sizes were designated in areas where the trees were more scattered (recreation/buffer zone) to enable capturing of more trees for assessment. Tree measurements by height, diameter at breast height (DBH), canopy, and coordinates were taken and recorded. The tools used in determining AGB included GPS receivers, Suunto clinometers, a compass, caliper, and diameter tape (Fig. 2).

The measurements taken were then used to calculate biomass using allometry. For trees with multi-stems, the quadratic mean diameter (QMD) was calculated using Eq. (1) below:

$$
\mathrm{QMD}=\sqrt{(\pi * B A) /(4 * N)}
$$


Table 2 Constants for the varying diameter classes used to convert field vegetation measures

\begin{tabular}{l|l|l|l|l}
\hline \multirow{2}{*}{ Diameter class } & \multicolumn{5}{l}{ Constants } & b & c & D \\
\cline { 2 - 5 } & a & 1.5445 & 0.50663 & 0.333346 \\
\hline DBH $<20 \mathrm{~cm}$ & -0.85989 & 1.943912 & 0.473731 & 0.245776 \\
\hline $20 \geq$ DBH $\leq 60 \mathrm{~cm}$ & -1.750891 & 2.032931 & 0.31292 & 0.436348 \\
\hline DBH $\geq 60 \mathrm{~cm}$ & -2.166502 & &
\end{tabular}

After Velle (1995)

Where:

QMD is quadratic mean diameter.

$\mathrm{BA}$ is total basal area $=\mathrm{ba} 1+\mathrm{ba} 2+\mathrm{ba} 3 \ldots \mathrm{ba}_{\mathrm{N}}$ is the number of stems.

To estimate AGB, a number of models were explored and tested in relation to the variables. Models which included the diameter as predictor variable, a combination of diameter and tree height, diameter and crown diameter, and finally the diameter, tree height, and crown diameter were tested. These models are the most commonly used for allometry development (Brown et al. 1989; Chave et al. 2005; 2014; Djomo et al. 2010, 2016). The generalized allometric equation by Velle (1995) equations developed for Uganda to estimate AGB was applied as stated in Eq. (2).

$$
\operatorname{Ln}(\mathrm{PWF})=\mathrm{a}+\mathrm{b} * \operatorname{Ln}(\mathrm{D})+\mathrm{c} * \operatorname{Ln}(\mathrm{HT})+\mathrm{d} * \operatorname{Ln}(\mathrm{CR})
$$

Where:

PWF is fresh weight of a stem and branches in $\mathrm{kg}$

$\mathrm{D}$ is $\mathrm{DBH}$ in $\mathrm{cm}$

HT is height of the tree in $\mathrm{m}$

$\mathrm{CR}$ is the width of the crown in meters.

$\mathrm{a}, \mathrm{b}, \mathrm{c}$, and $\mathrm{d}$ are constants for all the pooled trees which may vary according to the diameter class as indicated in Table 2 below.

The application of the generalized allometric equation is avouched by its use even in highly diverse systems, where more than $95 \%$ of the variation in AGB is explained by DBH alone (Brown 2002). The fresh weight was then converted to dry weight for biomass detection by taking $50 \%$ of the wet weight (Gates et al. 1982). Below-ground biomass (BGB) was estimated by taking $20 \%$ of AGB (Mokany et al. 2006). From this, the total biomass per tree and per hectare was also calculated. Subsequently, carbon was converted into carbon sequestered (CO equivalents) by multiplying it with a factor of (44/12), which is the carbon dioxidecarbon molecular weight ratio (Penman et al. 2003). To assess the variation in biomass and carbon stocks for the different management zones, Anova for XLSTAST (version 3.1.3) was applied. 
The UBOS 2017 shapefile was used to estimate the total size of areas covered by the three management zones as indicated in Fig. 1. Data collected were analyzed using XLSTAST. The biomass was converted to carbon (C) by assuming a $50 \%$ biomass to carbon content (Brown 1997; Losi et al. 2003; Penman et al. 2003; Change 2006; FAO 2005).

\section{Estimating Soil Organic Carbon}

According to Rau et al. (2011), the excavation of soil pits has been identified as a widely applicable and universally accepted method for the assessment of soil organic carbon (SOC). Samples of $50 \mathrm{~m} \times 50 \mathrm{~m}$ plots up to $30 \mathrm{~cm}$ deep for the $\mathrm{SOC}$ pool were taken from the three management zones of the Mabira CFR and environs. Four dominant land use types, viz.: built-up area, plantations (sugarcane and/tea), subsistence farming, and forest were considered in each management zone. From each zone, 44 samples were taken, considering at least 3 points in each land use/cover type. A total of 132 soil samples were extracted from the 44 spots, taking three replicates from soil depth of $0-10 \mathrm{~cm}, 10-20 \mathrm{~cm}$, and $20-30 \mathrm{~cm}$. On completion of sample collection, the unwanted materials like stones, granules, plant parts, leaves, etc. were discarded. The soil samples were kept in polythene bags, tightly closed and well labeled. The bags were stored at $5{ }^{\circ} \mathrm{C}$ to limit microbial degradation, oxidation, and volatilization activities.

In the laboratory, samples were air dried and sieved through a 2-mm sieve. The sieved sample was used for SOC estimation. The samples were analyzed using wet oxidation method (Walkley and Black 1934), using potassium dichromate $\left(\mathrm{K}_{2} \mathrm{Cr}_{2} \mathrm{O}_{7}\right)$ and concentrated sulfuric acid $\left(\mathrm{H}_{2} \mathrm{SO}_{4}\right)$. The samples were oven dried and a sample reagent mixture was prepared using standard laboratory procedures. The mixture was titrated with ferrous ammonium sulfate to determine the amount of organic carbon. Back titration was then performed until the color of the solution turned brown, which marked the end point. A standardization blank (without soil) was also run in the same way. Equation (3) was used to extract the carbon content.

$$
\mathrm{BT}-\mathrm{ST}(0.3 \times 5) / 0.3 \times 9.8
$$

Where:

$\mathrm{BT}=$ blank titer, which was considered at 9.8

$\mathrm{ST}=$ unused dichromate

All data were analyzed using SPSS statistical software version 16.0. Analysis of variance (ANOVA) was carried out using the two-factor randomized complete plot design. Significant F-values were obtained; differences between individual means were tested using the least significant difference (LSD) test. To assess variations in biomass and carbon stocks for the different management zones, Anova for XLSTAST (version 3.1.3) was applied. 


\section{AGB and Carbon Stocks}

Average AGB and AGC based on tree parameters comprising height, $\mathrm{DBH}$, and crown diameter, as presented in Table 3 were 890.9 and $445.63 \mathrm{~kg}$, respectively. Biomass and carbon totals of 1069.1 and $534.6 \mathrm{~kg}$, respectively are also evident. A linear relationship between biomass and carbon stocks is presented in Fig. 3. The RSquared statistic indicates that the model as fitted explains $100.0 \%$ of the variability in carbon stocks (tonnes per hectare). The correlation coefficient is 1.0 , signifying a perfectly strong relationship between the two variables. Since the P-value is greater than 0.05 , there is no indication of serial autocorrelation in the residuals at the $95.0 \%$ confidence level. BGB was estimated by applying the $20 \%$ conversion rate to AGB (Mokany et al. 2006). Similarly, 50\% of the BGB is taken as the estimation for BGC, results of which are presented in Table 3.

Variations of biomass and carbon stocks were noted in the different management zones. The highest average total AGB was found in the strict nature reserve, where values of the multiparameters of $\mathrm{DBH}$, height and crown diameter were highest as well. The production zone, which had scattered trees with smaller parameters registered the lowest average total AGB (Table 4). Whereas the strict nature reserve had the highest carbon stocks, the production zone registered the least (Tables 5 and 6).

The ANOVA (Table 7) decomposes the variance of carbon stocks ( $\mathrm{kg}$ per tree) into two components: a between-group and within-group components. The F-ratio, which in this case is 13.97 , is a ratio of the between-group estimate to the withingroup estimate. Since the P-value of the F-test is less than 0.05 , there is a statistically significant difference between the mean carbon stocks (tonnes per hectare) from one management zone to another at the 5\% significance level. To determine which means are significantly different from others, multiple range tests were selected from the list of tabular options.

The multiple comparison procedure is applied (Table 8) to determine which means are significantly different from others. The bottom half of the output shows the estimated difference between each pair of means. An asterisk to signify statistically significant differences at the $95.0 \%$ confidence level has been placed next to the pairs. In the table, two homogenous groups are identified using columns of Xs. Within each column, the levels containing Xs form a group of means within which there are no statistically significant differences. According to Fisher's least significant difference (LSD) procedure used to discriminate among the means, there is a $5 \%$ risk of calling each pair of means significantly different when the actual difference is 0 (Fig. 4).

A comparison of tree carbon stocks and sequestration per management zone was also done, and it was revealed that the highest carbon is in the strict nature reserve and least in the production zone as shown in Table 9.

It is noticeable from Tables 9 and 10 that carbon sinking varies between the management zones. Table 10 shows that the strict nature reserve management zone sinks the highest volume of carbon of approximately 6,771,092.34 tonnes, despite its small coverage in comparison to the recreation/buffer $(2,196,467.59$ tonnes) and production zones $(458,903.57$ tonnes). 


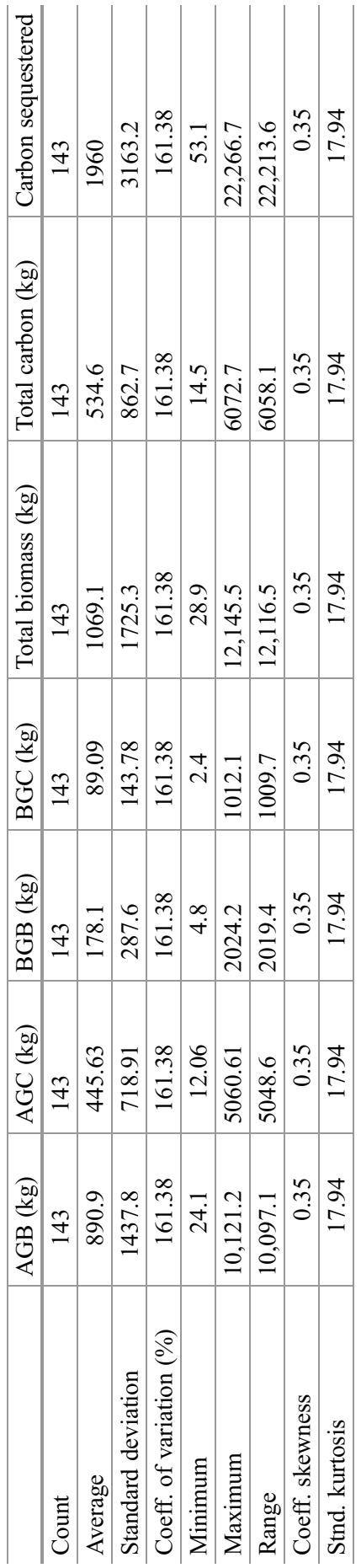




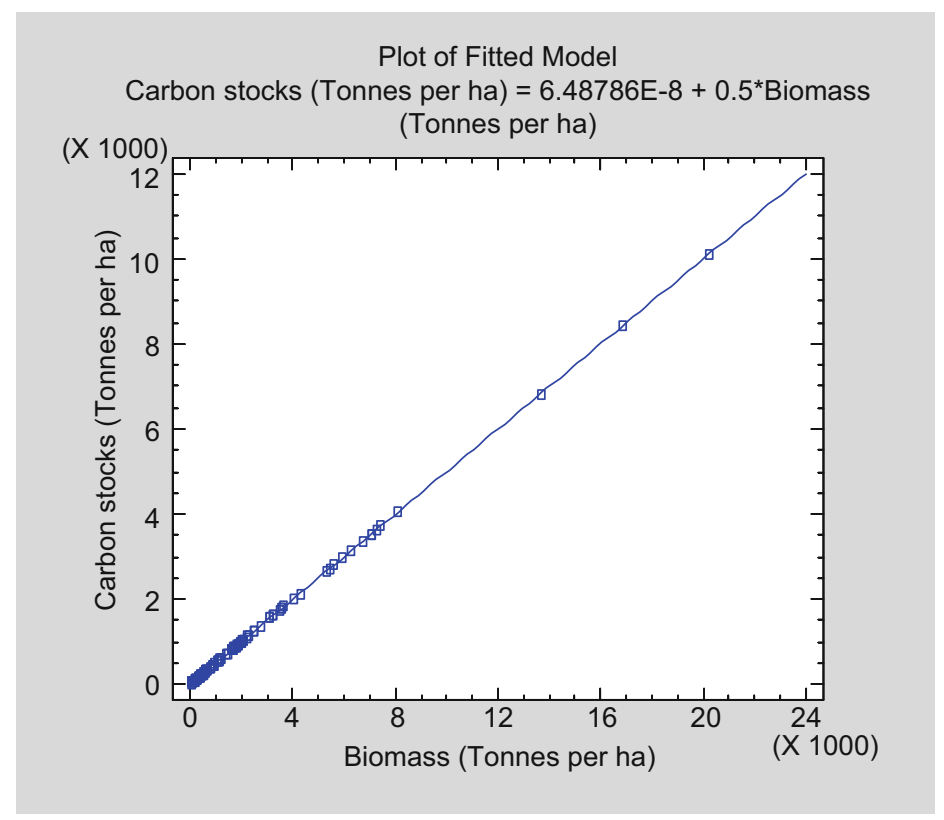

Fig. 3 Relationship between biomass and carbon

Table 4 Summary statistics for average tree biomass stocks $(\mathrm{kg})$

\begin{tabular}{l|c|l|l|l|l|l}
\hline $\begin{array}{l}\text { Management } \\
\text { zones }\end{array}$ & Count & $\begin{array}{l}\text { Average } \\
\text { biomass } \\
(\mathrm{kg})\end{array}$ & $\begin{array}{l}\text { Standard } \\
\text { deviation }\end{array}$ & $\begin{array}{l}\text { Coeff. of } \\
\text { variation } \\
(\%)\end{array}$ & Minimum & Maximum \\
\hline $\begin{array}{l}\text { Production } \\
\text { zone }\end{array}$ & 30 & 181.436 & 319.433 & 176.059 & 24.124 & 1783.39 \\
\hline $\begin{array}{l}\text { Recreation/ } \\
\text { buffer zone }\end{array}$ & 50 & 506.0548 & 627.4903 & 123.9965 & 36.3592 & 3117.55 \\
\hline $\begin{array}{l}\text { Strict nature } \\
\text { reserve }\end{array}$ & 63 & 1534.23 & 1895.35 & 123.537 & 37.1147 & $10,121.2$ \\
\hline Total & 143 & 887.516 & 1439.42 & 162.186 & 24.124 & $10,121.2$ \\
\hline
\end{tabular}

It is also important to compare SOC in forest environments. Comparison for variations of soil organic carbon in Mabira forest was done basing on the SOC percentage content. It was noted that there was no variation in the mean SOC for the three management zones. In terms of soil depth, the $0-10 \mathrm{~cm}$ and $10-20 \mathrm{~cm}$ soil layers had relatively similar variations of least square means for carbon than the 20 $30 \mathrm{~cm}$ soil layer. The highest SOC was observed in the soil surface of $0-10 \mathrm{~cm}$ depth, with the highest mean of $2.78 \%$ across all the management zones. As expected, soil organic matter decreases with depth and varies with land use/cover type. Whereas the forest and subsistence farming land use/cover types had relatively higher means of SOC (with legumes and bananas as dominant crops), low mean variations for 
Table 5 Descriptive statistics for carbon stocks (kg per tree) by management zones

\begin{tabular}{|c|c|c|c|c|c|c|c|c|}
\hline \multicolumn{9}{|l|}{ Description } \\
\hline \multicolumn{9}{|l|}{ Carbon } \\
\hline & \multirow[b]{2}{*}{$\mathrm{N}$} & \multirow[b]{2}{*}{ Mean } & \multirow[b]{2}{*}{$\begin{array}{l}\text { Std. } \\
\text { deviation }\end{array}$} & \multirow[b]{2}{*}{$\begin{array}{l}\text { Std. } \\
\text { error }\end{array}$} & \multicolumn{2}{|c|}{$\begin{array}{l}\text { 95\% Confidence } \\
\text { interval for mean }\end{array}$} & \multirow[b]{2}{*}{ Min. } & \multirow[b]{2}{*}{ Max. } \\
\hline & & & & & $\begin{array}{l}\text { Lower } \\
\text { bound }\end{array}$ & $\begin{array}{l}\text { Upper } \\
\text { bound }\end{array}$ & & \\
\hline $\begin{array}{l}\text { Strict nature } \\
\text { reserve }\end{array}$ & 63 & 920.54 & 1137.21 & 143.275 & 634.14 & 1206.94 & 22 & 6073 \\
\hline $\begin{array}{l}\text { Recreation } \\
\text { buffer }\end{array}$ & 50 & 303.63 & 376.49 & 53.244 & 196.63 & 410.63 & 22 & 1871 \\
\hline $\begin{array}{l}\text { Production } \\
\text { zone }\end{array}$ & 30 & 108.86 & 191.66 & 34.992 & 37.29 & 180.43 & 14 & 1070 \\
\hline Total & 143 & 534.56 & 862.69 & 72.142 & 391.95 & 677.17 & 14 & 6073 \\
\hline
\end{tabular}

Table 6 Variance of carbon stocks ( $\mathrm{kg}$ per tree) by management zone

\begin{tabular}{l|l|r|r|l|l}
\hline Source of variations & Sum of squares & \multicolumn{1}{|c|}{ d.f. } & Mean square & F-ratio & Sig. \\
\hline Between groups & $1.749 \mathrm{E} 7$ & 2 & $8,744,327.239$ & 13.881 & 0.000 \\
\hline Within groups & $8.819 \mathrm{E} 7$ & 140 & $629,941.672$ & & \\
\hline Total (corr.) & $1.057 \mathrm{E} 8$ & 142 & & &
\end{tabular}

Table 7 Analysis of variance for carbon stocks ( $\mathrm{kg}$ per tree) - type III sums of squares

\begin{tabular}{l|l|l|l|l|l}
\hline Source & Sum of squares & d.f. & Mean square & F-ratio & $P$-value \\
\hline Main effects & & & & & \\
\hline \multicolumn{1}{c}{ Management zones } & 4.89 & 2 & 2.44 & 13.97 & 0.0000 \\
\hline Residual & 2.45 & 140 & 1.75 & & \\
\hline Total (corrected) & 2.94 & 142 & & & \\
\hline
\end{tabular}

All F-ratios are based on the residual mean square error

carbon were recorded in both the tea and sugarcane plantations, and built-up areas (Table 11 and Fig. 5).

Among the three factors (soil depth, management zones, land use/cover types) assessed for SOC variations, it was soil depth and land use/cover types that had a statistically significant effect on the percentage of carbon $(P=0.05)$, as presented in Table 12.

\section{Discussion}

Velle (1995) allometric equation was adopted and here combinations of tree parameters are applied. Similar recommendations for specific diameter-height allometries are made in studies by Feldpausch et al. (2011) and Banin et al. (2012). According to Sharifi et al. (2016), blending parameters may give better results. Although DBH was found to be a significant parameter in determining AGB and C (Dudley and 


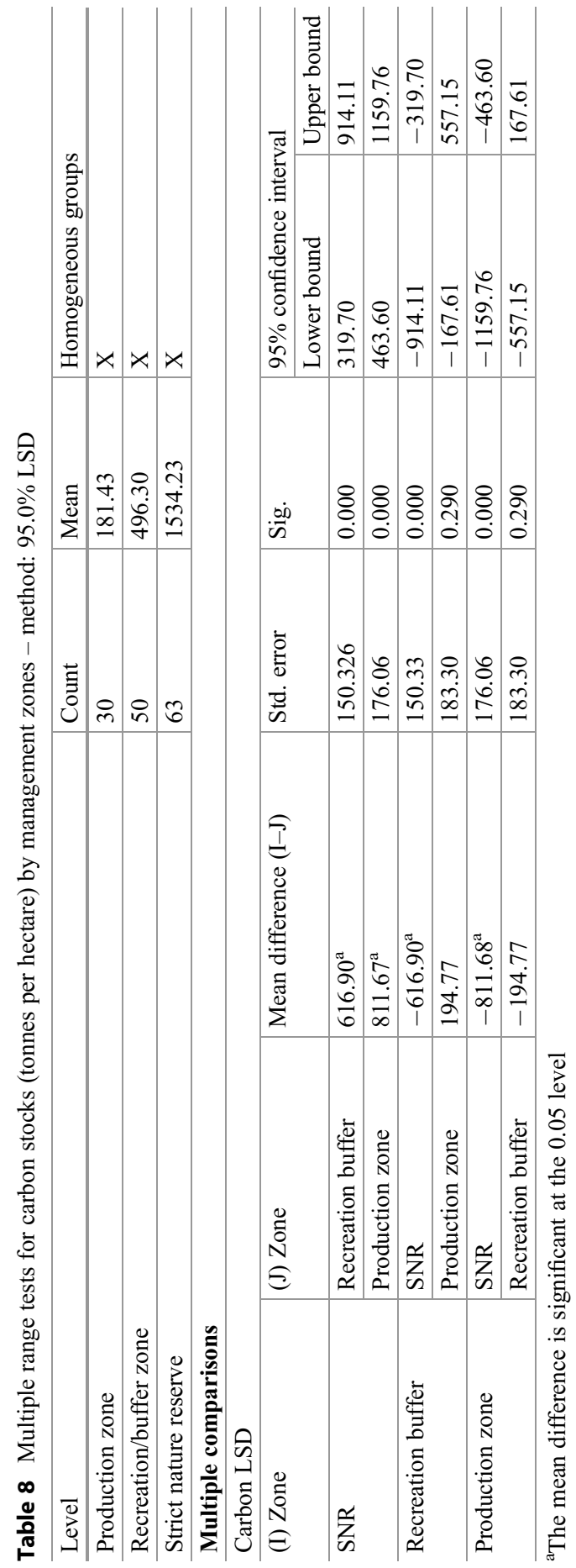




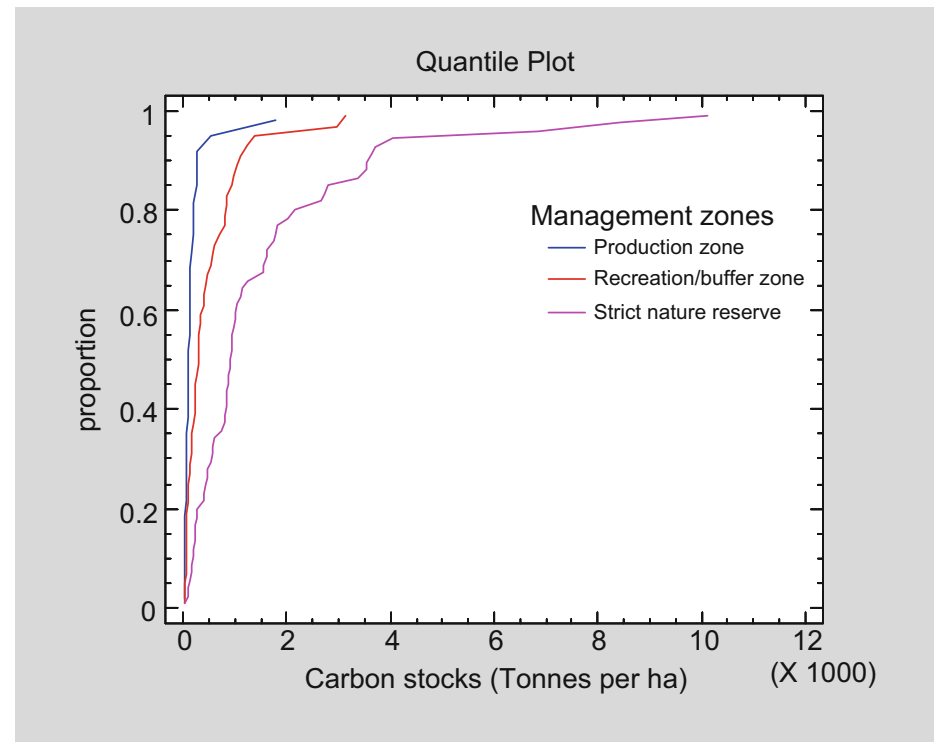

Fig. 4 Carbon stocks in the different management zones, indicating highest carbon concentrations in the strict nature reserve

Table 9 Average biomass, carbon, and carbon sequestered per tree in the management zones of Mabira CFR

\begin{tabular}{l|l|l|l}
\hline Management zone & Biomass $/ \mathrm{kg}$ & Carbon stock $/ \mathrm{kg}$ & Carbon sequestered \\
\hline Strict nature reserve & $1841 \pm 321.7$ & $920.5 \pm 160.8$ & $3375 \pm 589.7$ \\
\hline Recreation/buffer & $607.2 \pm 106.5$ & $303.6 \pm 53$ & $1113 \pm 195$ \\
\hline Production & $217.7 \pm 54.2$ & $108.9 \pm 27.1$ & $399.2 \pm 99.4$ \\
\hline
\end{tabular}

Fownes 1992), it was also noted that higher estimations of AGB and carbon were indicated where $\mathrm{DBH}$ and $\mathrm{H}$ were combined. It was also noted that a coefficient of 1.0 indicated a perfectly strong relationship between AGB and carbon. Such a significant logarithmic relationship was also identified by Clark et al. (2001) and Krisnawati et al. (2012).

The results reveal a positive relationship between land use/cover and carbon sequestration, since the strict nature reserve has more AGB stocks. Therefore, conservation of forests with large carbon stocks would reduce carbon dioxide emissions than the production zone, where pockets of degradation are evident, despite isolated afforestation and reforestation attempts. The findings are in keeping with Sharma et al. (2010), implying that preserving old growth strands maintains large amounts of carbon stocks and also promotes sequestration of much more carbon than exotic forests.

The strict nature reserve covering 3857 ha sinks approximately 6,771,092.34 tonnes. However, government plans to reduce this area to 3189 ha and increase the production 


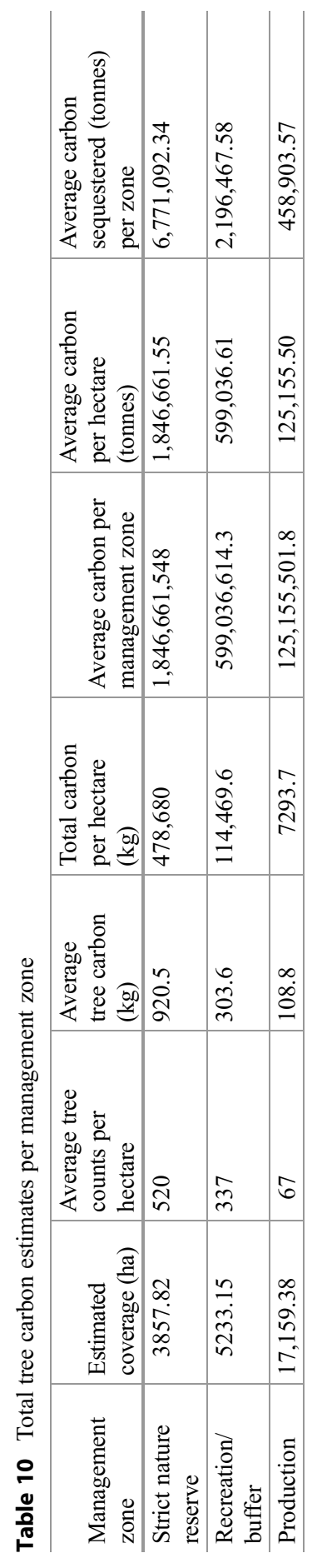


Table 11 Least squares means for SOC with $95.0 \%$ confidence intervals

\begin{tabular}{l|l|l|l|l|l}
\hline Level & Count & Mean (\%) & Std. error & Lower limit & Upper limit \\
\hline Grand mean & 132 & 2.17994 & & & \\
\hline Soil depth & & & & & \\
\hline $0-10 \mathrm{~cm}$ & 44 & 2.78 & 0.16 & 2.47 & 3.09 \\
\hline $10-20 \mathrm{~cm}$ & 44 & 2.17 & 0.15 & 1.87 & 2.47 \\
\hline $20-30 \mathrm{~cm}$ & 44 & 1.59 & 0.15 & 1.28 & 1.89 \\
\hline Management zones & & & & & \\
\hline Production zone & 24 & 2.25 & 0.21 & 1.82 & 2.67 \\
\hline Recreation/buffer zone & 60 & 2.11 & 0.12 & 1.88 & 2.35 \\
\hline Strict nature reserve & 48 & 2.18 & 0.14 & 1.88 & 2.47 \\
\hline Land use/cover types & & & & & \\
\hline Built-up & 24 & 1.88 & 0.19 & 1.49 & 2.26 \\
\hline Forest & 36 & 2.81 & 0.15 & 2.52 & 3.10 \\
\hline Subsistence farming & 40 & 2.45 & 0.14 & 2.17 & 2.73 \\
\hline Sugarcane plantation & 26 & 1.86 & 0.19 & 1.50 & 2.25 \\
\hline Tea plantation & 6 & 1.89 & 0.38 & 1.14 & 2.63
\end{tabular}

zone to 26,785 ha (NFA 2017). This would reduce the carbon sink and pave the way for further global warming, related to unsustainable agricultural practices, which include deforestation, bush burning, overgrazing, monoculture, and overcultivation, all of which degrade the environment.

Soils are the main terrestrial carbon sink; the conservation of soil carbon reduces carbon emissions, as well as the risks of climate change. Land use and cover change are noted to significantly influence carbon variations. Under the strict nature reserve, where the dominant land cover type is forest, most of the activities are conservational, hence more carbon stocks, as opposed to the plantation area, which is more commercial with lower carbon stocks. This is in keeping with studies by Desjardins et al. (2004) and Meyer et al. (2012). Furthermore, SOC was found highest in the top layer of soil $(0-10 \mathrm{~cm})$. This is explained by the rapid decomposition of forest litter, which provides abundant organic matter. This is corroborated by studies by Mendoza-Vega et al. (2003) and Chowdhury et al. (2007), where more SOC was identified as located at the soil depth of $0-14 \mathrm{~cm}$. Furthermore, the highest and lowest AGC concentration was identified in the strictly managed and production zones, respectively. This is in conformity with findings by Brakas and Aune (2011), who noted that AGC stocks were very low in degraded, as opposed to preserved forests.

Land management practices can significantly affect the content and distribution of SOC in different vegetation types ( $\mathrm{Li}$ et al. 2014; Zhang et al. 2014; Baritz et al. 2010). The highest SOC concentrations were noted in the production zone and lowest in the recreation/buffer zone. By implication, if well managed through conservation attempts such as afforestation, reforestation, longer fallows and mulching, agricultural soils have a great potential for carbon sinking. Studies by 


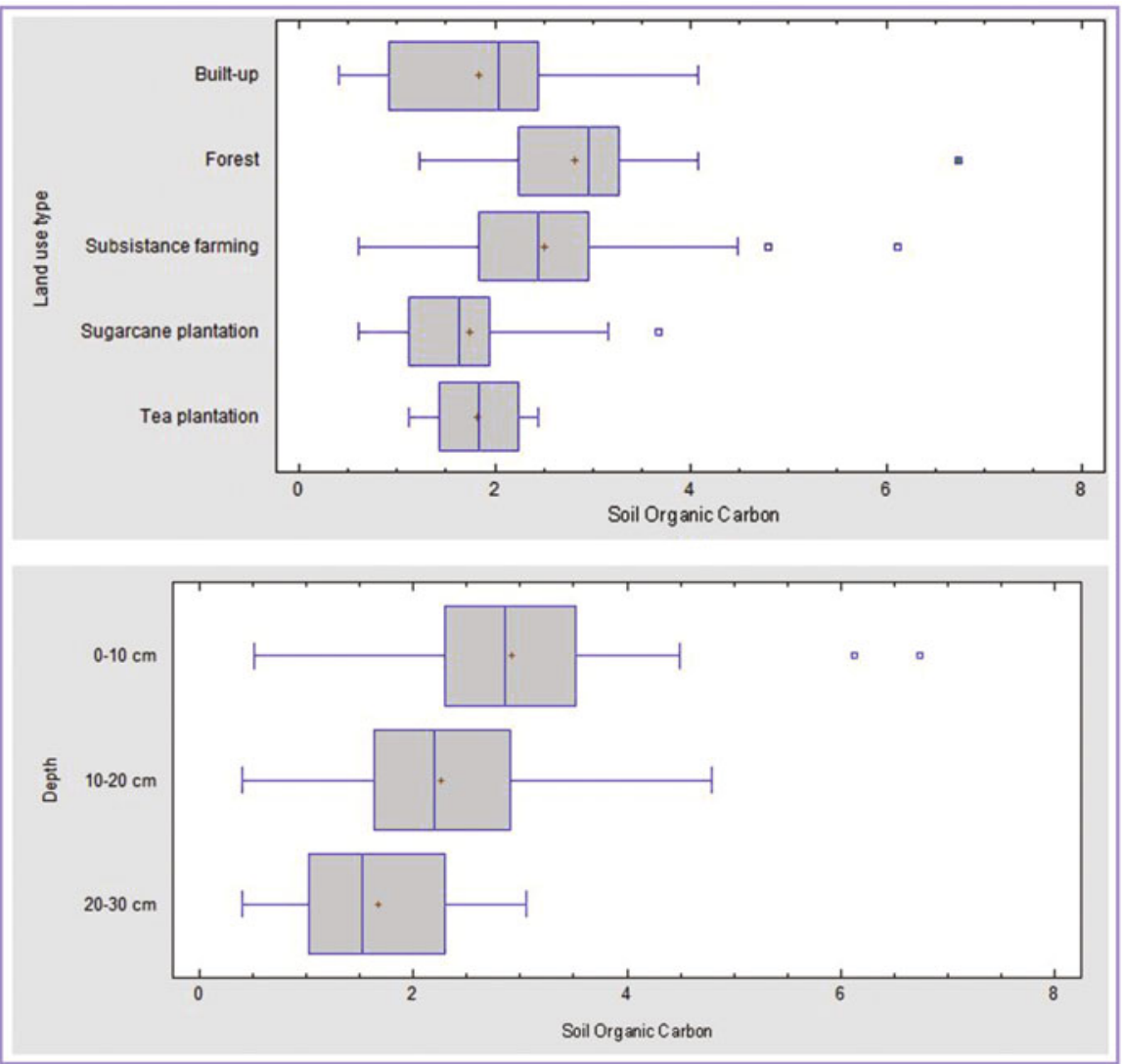

Fig. 5 Percentage SOC variations per land use/cover type, management zone, and soil depth

Table 12 Analysis of variance for SOC - type III sums of squares

\begin{tabular}{l|l|l|l|l|l}
\hline Source & Sum of squares & d.f. & Mean square & F-ratio & $P$-value \\
\hline Main effects & & & & & \\
\hline Soil depth & 31.0391 & 2 & 15.5195 & 19.89 & $0.0000^{\mathrm{a}}$ \\
\hline Management zone & 0.282212 & 2 & 0.141106 & 0.18 & 0.8348 \\
\hline$\quad$ Land use type & 17.1589 & 4 & 4.28971 & 5.50 & $0.0004^{\mathrm{a}}$ \\
\hline Residual & 95.985 & 123 & 0.780366 & & \\
\hline Total (corrected) & 152.692 & 131 & & & \\
\hline
\end{tabular}

All F-ratios are based on the residual mean square error

${ }^{a}$ Significant at $0.05 \%$ level of significance

McKinley et al. (2011) and Ryan et al. (2010) indicate that reducing the amount of forest harvest can decrease carbon losses to the atmosphere. As stated by Schwilk et al. (2009) and Stephens et al. (2012), forest disturbances can lead to additional soil carbon losses through soil erosion inducement. 


\section{Conclusion}

The main aim of this chapter was to assess the effect of forest management options on biomass and SOC variations in Mabira CFR. AGB and carbon stocks ( $\mathrm{t} / \mathrm{ha}$ ) of forest (trees) and SOC were estimated using allometric equations and sampling techniques. A multiparameter assessment of $\mathrm{DBH}, \mathrm{H}$, and crown diameter, and soil samples of $0-30$ depth provided replicable results for tree strand AGB and SOC.

The highest AGB was evident in areas where forest was still intact (strict nature reserve), as opposed to the degraded and encroached areas (production zone). SOC varied with soil depth and land use/cover types. Another important revelation in this chapter is that SOC concentration is greatest in the production zone. By implication, if well managed through conservation measures such as afforestation, reforestation, longer fallow periods, and mulching, SOC in legume enhanced agricultural soils have a great potential as carbon sinks. The lowest SOC was noted in the recreation/ buffer zone $(0.4 \%)$. Land use type, AGB, and forest management in the different zones are identified as the key drivers of carbon stock variations in Mabira CFR. Priority should be given to reducing deforestation and restore degraded areas. This can be achieved through demarcating forest boundaries to minimize encroachment, enforcement of policy on forestry for sustainable development, and promotion of reforestation programs.

\section{References}

Arsanjani JJ (2012) Analysis of results. In: Dynamic land use/cover change modelling. Springer, Berlin/Heidelberg, pp 109-130

Baccini AGSJ, Goetz SJ, Walker WS, Laporte NT, Sun M, Sulla-Menashe D, Hackler J, Berk PSA, Dubayah R, Friedl MA, Samanta S (2012) Estimated carbon dioxide emissions from tropical deforestation improved by carbon-density maps. Nat Clim Chang 2(3):182

Banin L, Feldpausch TR, Phillips OL (2012) Cross-continental comparisons of maximum tree height and allometry: testing environmental, structural and floristic drivers. Glob Ecol Biogeogr 21:1179-1190

Baritz R, Seufert G, Montanarella L, Van Ranst E (2010) Carbon concentrations and stocks in forest soils of Europe. For Ecol Manag 260(3):262-277

Basuki TM, Van Laake PE, Skidmore AK, Hussin YA (2009) Allometric equations for estimating the above-ground biomass in tropical lowland Dipterocarp forests. For Ecol Manag 257 (8):1684-1694

Beets PN, Kimberley MO, Oliver GR, Pearce SH, Graham JD, Brandon A (2012) Allometric equations for estimating carbon stocks in natural forest in New Zealand. Forests 3(3):818-839

Brakas SG, Aune JB (2011) Biomass and carbon accumulation in land use systems of Claveria, the Philippines. In: Carbon sequestration potential of agroforestry systems. Springer, Dordrecht, pp $163-175$

Brown S (1997) Estimating biomass and biomass change of tropical forests: a primer. FAO forestry paper 134. Food and Agriculture Organization of the United Nations, Rome

Brown S (2002) Measuring carbon in forests: current status and future challenges. Environ Pollut 116(3):363-372

Brown S, Lugo AE (1984) Biomass of tropical forests: a new estimate based on forest volumes. Science 223(4642):1290-1293 
Brown S, Gillespie AJ, Lugo AE (1989) Biomass estimation methods for tropical forests with applications to forest inventory data. For Sci 35(4):881-902

Bush G, Nampindo S, Aguti C, Plumptre A (2004) The value of Uganda's forests: a livelihoods and ecosystems approach. Wildlife Conservation Society, Kampala

Change IPOC (2006) IPCC guidelines for national greenhouse gas inventories. Institute for Global Environmental Strategies, Hayama, Kanagawa, Japan.

Chave J, Andalo C, Brown S, Cairns MA, Chambers JQ, Eamus D, Fölster H, Fromard F, Higuchi N, Kira T, Lescure JP (2005) Tree allometry and improved estimation of carbon stocks and balance in tropical forests. Oecologia 145(1):87-99

Chave J, Réjou-Méchain M, Búrquez A, Chidumayo E, Colgan MS, Delitti WB, Duque A, Eid T, Fearnside PM, Goodman RC, Henry M (2014) Improved allometric models to estimate the aboveground biomass of tropical trees. Glob Chang Biol 20(10):3177-3190

Chen W, Li J, Zhang Y, Zhou F, Koehler K, LeBlanc S, Fraser R, Olthof I, Zhang Y, Wang J (2009) Relating biomass and leaf area index to non-destructive measurements in order to monitor changes in Arctic vegetation. Arctic 62:281-294

Chowdhury MSH, Biswas S, Halim MA, Haque SS, Muhammed N, Koike M (2007) Comparative analysis of some selected macronutrients of soil in orange orchard and degraded forests in Chittagong Hill Tracts, Bangladesh. J For Res 18(1):27-30

Clark DA, Brown S, Kicklighter DW, Chambers JQ, Thomlinson JR, Ni J, Holland EA (2001) Net primary production in tropical forests: an evaluation and synthesis of existing field data. Ecol Appl 11(2):371-384

Desjardins T, Barros E, Sarrazin M, Girardin C, Mariotti A (2004) Effects of forest conversion to pasture on soil carbon content and dynamics in Brazilian Amazonia. Agric Ecosyst Environ 103 (2):365-373

Dixon RK, Solomon AM, Brown S, Houghton RA, Trexier MC, Wisniewski J (1994) Carbon pools and flux of global forest ecosystems. Science 263(5144):185-190

Djomo AN, Ibrahima A, Saborowski J, Gravenhorst G (2010) Allometric equations for biomass estimations in Cameroon and pan moist tropical equations including biomass data from Africa. For Ecol Manag 260(10):1873-1885

Djomo AN, Picard N, Fayolle A, Henry M, Ngomanda A, Ploton P, McLellan J, Saborowski J, Adamou I, Lejeune P (2016) Tree allometry for estimation of carbon stocks in African tropical forests. Forestry 89(4):446-455

Dudley NS, Fownes JH (1992) Preliminary biomass equations for eight species of fast-growing tropical trees. J Trop For Sci 5:68-73

Ellis E, Pontius R (2007) Land-use and land-cover change. Encyclopedia of earth 1-4

FAO (2010) Global forest resources assessment 2000. FAO forestry paper, 140. FAO, Rome. Agriculture Organization of the United Nations. (2001)

FAO (2011) La situation des forêts dans le bassin amazonien, le bassin du Congo et l'Asie du SudEst. FAO, ITTO, Sommet des trois Bassins Forestiers Tropicaux, Brazzaville

FAO (2016) State of the World's Forests 2016. Forests and agriculture: land-use challenges and opportunities. FAO, Rome

Feldpausch TR, Banin L, Phillips OL, Baker TR, Lewis SL, Quesada CA, Affum-Baffoe K, Arets EJ, Berry NJ, Bird M, Brondizio ES (2011) Height-diameter allometry of tropical forest trees. Biogeosciences 8:1081-1106

Foley JA, DeFries R, Asner GP, Barford C, Bonan G, Carpenter SR, Chapin FS, Coe MT, Daily GC, Gibbs HK, Helkowski JH (2005) Global consequences of land use. Science 309(5734):570-574

Gates MA, Rogerson A, Berger J (1982) Dry to wet weight biomass conversion constant for Tetrahymena elliotti (Ciliophora, Protozoa). Oecologia 55(2):145-148

Hairiah K, Dewi S, Agus F, Velarde S, Ekadinata A, Rahayu S, van Noordwijk M (2011) Measuring carbon stocks across land use systems. World Agroforestry Centre, Bogor

Harris NL, Brown S, Hagen SC, Saatchi SS, Petrova S, Salas W, Hansen MC, Potapov PV, Lotsch A (2012) Baseline map of carbon emissions from deforestation in tropical regions. Science 336 (6088):1573-1576 
Hashim JH, Hashim Z (2016) Climate change, extreme weather events, and human health implications in the Asia Pacific region. Asia Pac J Public Health 28(2 Suppl):8S-14S

Henry M, Picard N, Trotta C, Manlay R, Valentini R, Bernoux M, Saint André L (2011) Estimating tree biomass of sub-Saharan African forests: a review of available allometric equations. Silva Fennica 45(3B):477-569

Howard PC, Davenport TRB (1996) Forest biodiversity reports. Uganda Forest Department, Kampala

Jandl R, Lindner M, Vesterdal L, Bauwens B, Baritz R, Hagedorn F, Johnson DW, Minkkinen K, Byrne KA (2007) How strongly can forest management influence soil carbon sequestration? Geoderma 137(3-4):253-268

Jjagwe A, Kakembo V, Barasa B (2017) An assessment of the spatial and temporal changes of Mabira tropical forest reserve and its environs, Central Uganda. Tanzania J Dev Stud 15(1-2):32-52

Kerr JT, Kharouba HM, Currie DJ (2007) The macroecological contribution to global change solutions. Science 316(5831):1581-1584

Krisnawati H, Adinugroho WC, Imanuddin R (2012) Monograph allometric models for estimating tree biomass at various forest ecosystem types in Indonesia. Research and Development Center for Conservation and Rehabilitation, Forestry Research and Development Agency, Ministry of Forestry, Bogor

Lambin EF, Geist HJ (eds) (2008) Land-use and land-cover change: local processes and global impacts. Springer Science \& Business Media, Dordrecht

Lepp A, Gibson H, Lane C (2011) Image and perceived risk: a study of Uganda and its official tourism website. Tour Manag 32(3):675-684

Li Y, Zhang J, Chang SX, Jiang P, Zhou G, Shen Z, Wu J, Lin L, Wang Z, Shen M (2014) Converting native shrub forests to Chinese chestnut plantations and subsequent intensive management affected soil C and N pools. For Ecol Manag 312:161-169

Losi CJ, Siccama TG, Condit R, Morales JE (2003) Analysis of alternative methods for estimating carbon stock in young tropical plantations. For Ecol Manag 184(1-3):355-368

McKinley DC, Ryan MG, Birdsey RA, Giardina CP, Harmon ME, Heath LS, Houghton RA, Jackson RB, Morrison JF, Murray BC, Pataki DE (2011) A synthesis of current knowledge on forests and carbon storage in the United States. Ecol Appl 21(6):1902-1924

Mendoza-Vega J, Karltun E, Olsson M (2003) Estimations of amounts of soil organic carbon and fine root carbon in land use and land cover classes, and soil types of Chiapas highlands, Mexico. For Ecol Manag 177(1-3):191-206

Meyer S, Leifeld J, Bahn M, Fuhrer J (2012) Free and protected soil organic carbon dynamics respond differently to abandonment of mountain grassland. Biogeosciences 9(2):853-865

Mokany K, Raison RJ, Prokushkin AS (2006) Critical analysis of root: shoot ratios in terrestrial biomes. Glob Chang Biol 12(1):84-96

Mokria M, Gebrekirstos A, Aynekulu E, Bräuning A (2015) Tree dieback affects climate change mitigation potential of a dry afromontane forest in northern Ethiopia. For Ecol Manag 344:73-83

MWE (2017) Mabira central forest reserves. 26 Jun 2020, Retrived from: https://www.mwe.go.ug/ library/forestry-documents

National Forestry Authority (2009) National Biomass Study Technical Report

Ngomanda A, Obiang NLE, Lebamba J, Mavouroulou QM, Gomat H, Mankou GS, Loumeto J, Iponga DM, Ditsouga FK, Koumba RZ, Bobé KHB (2014) Site-specific versus pantropical allometric equations: which option to estimate the biomass of a moist central African forest? For Ecol Manag 312:1-9

Ochoa-Gaona S, Gonzalez-Espinosa M (2000) Land use and deforestation in the highlands of Chiapas, Mexico. Appl Geogr 20:17-42

Olson JS, Watts JA, Allison LJ (1983) Carbon in live vegetation of major world ecosystems (no. 1997). Oak Ridge National Laboratory, Oak Ridge

Parresol BR (1999) Assessing tree and stand biomass: a review with examples and critical comparisons. For Sci 45(4):573-593 
Parry M, Parry ML, Canziani O, Palutikof J, Van der Linden P, Hanson C (eds) (2007) Climate change 2007 - impacts, adaptation and vulnerability: working group II contribution to the Fourth Assessment Report of the IPCC, vol 4. Cambridge University Press, Cambridge, UK

Penman J, Gytarsky M, Hiraishi T, Krug T, Kruger D, Pipatti R, Buendia L, Miwa K, Ngara T, Tanabe K, Wagner F (2003) Good practice guidance for land use, land-use change and forestry. Good practice guidance for land use, land-use change and forestry

Rau BM, Melvin AM, Johnson DW, Goodale CL, Blank RR, Fredriksen G, Miller WW, Murphy JD, Todd Jr, DE, Walker RF (2011) Revisiting soil carbon and nitrogen sampling: Quantitative pits versus rotary cores. Soil science 176(6):273-279

Ryan MG, Harmon ME, Birdsey RA, Giardina CP, Heath LS, Houghton RA, Jackson RB, McKinley DC, Morrison JF, Murray BC, Pataki DE (2010) A synthesis of the science on forests and carbon for US forests. Ecol Soc Am: Issues Ecol 13:1-16

Schimel DS, House JI, Hibbard KA, Bousquet P, Ciais P, Peylin P, Braswell BH, Apps MJ, Baker D, Bondeau A, Canadell J (2001) Recent patterns and mechanisms of carbon exchange by terrestrial ecosystems. Nature 414(6860):169

Schwarz S, Fakultät für Geomatik, Hochschule Karlsruhe-Technik und Wirtschaft (2010) The BIOTA East Africa atlas: rainforest change over time. Faculty of Geomatics, Karlsruhe University of Applied Sciences, Karlsruhe

Schwilk DW, Keeley JE, Knapp EE, McIver J, Bailey JD, Fettig CJ, Fiedler CE, Harrod RJ, Moghaddas JJ, Outcalt KW, Skinner CN (2009) The National Fire and Fire Surrogate Study: effects of fuel reduction methods on forest vegetation structure and fuels. Ecol Appl 19(2):285-304

Sharifi A, Amini J, Tateishi R (2016) Estimation of forest biomass using multivariate relevance vector regression. Photogramm Eng Remote Sens 82(1):41-49

Sharma CM, Baduni NP, Gairola S, Ghildiyal SK, Suyal S (2010) Tree diversity and carbon stocks of some major forest types of Garhwal Himalaya, India. For Ecol Manag 260(12):2170-2179

Shrestha DP, Zinck JA, Van Ranst E (2004) Modelling land degradation in the Nepalese Himalaya. Catena 57(2):135-156

Stephens SL, McIver JD, Boerner RE, Fettig CJ, Fontaine JB, Hartsough BR, Kennedy PL, Schwilk DW (2012) The effects of forest fuel-reduction treatments in the United States. Bioscience 62 (6):549-545

Tackenberg O (2007) A new method for non-destructive measurement of biomass, growth rates, vertical biomass distribution and dry matter content based on digital image analysis. Ann Bot 99 (4):777-783

Thornes JE (2002) In: McCarthy JJ, OF Canziani, Leary NA, Dokken DJ, White KS (eds) IPCC 2001. Climate change 2001: impacts, adaptation and vulnerability, contribution of working group II to the Third Assessment Report of the Intergovernmental Panel on Climate Change. Cambridge University Press, Cambridge, UK/New York, p 1032. ISBN 0-521-01500-6 (paperback), ISBN 0-521-80768-9 (hardback). Int J Climatol: J R Meteorol Soc 22(10):1285-1286

Turyahabwe N, Agea JG, Tweheyo M, Tumwebaze SB (2012) Collaborative forest management in Uganda: benefits, implementation challenges and future directions. Sustainable Forest Management: Case Studies 51.

UBOS, U. (2010) 2010 Statistical abstract

UNEP (2002) Global environmental outlook: 3. Past, present and future perspectives. Earthscan Publications, London

Velle K (1995) Estimation of standing stock of woody biomass in areas where little or no baseline data are available. A study based on field measurements in Uganda. Norges Landbrukshoegskole, Ås

Walkley A, Black IA (1934) An examination of the Degtjareff method for determining soil organic matter, and a proposed modification of the chromic acid titration method. Soil Sci 37(1):29-38

Watson RT, Noble IR, Bolin B, Ravindranath NH, Verardo DJ, Dokken DJ (2000) Land use, landuse change and forestry: a special report of the Intergovernmental Panel on Climate Change. Cambridge University Press, Cambridge, UK 
Zhang J, Li Y, Chang SX, Jiang P, Zhou G, Liu J, Wu J, Shen Z (2014) Understory vegetation management affected greenhouse gas emissions and labile organic carbon pools in an intensively managed Chinese chestnut plantation. Plant Soil 376(1-2):363-375

Zheng D, Rademacher J, Chen J, Crow T, Bresee M, Le Moine J, Ryu SR (2004) Estimating aboveground biomass using Landsat $7 \mathrm{ETM}+$ data across a managed landscape in northern Wisconsin, USA. Remote Sens Environ 93(3):402-411

Open Access This chapter is licensed under the terms of the Creative Commons Attribution 4.0 International License (http://creativecommons.org/licenses/by/4.0/), which permits use, sharing, adaptation, distribution and reproduction in any medium or format, as long as you give appropriate credit to the original author(s) and the source, provide a link to the Creative Commons license and indicate if changes were made.

The images or other third party material in this chapter are included in the chapter's Creative Commons license, unless indicated otherwise in a credit line to the material. If material is not included in the chapter's Creative Commons license and your intended use is not permitted by statutory regulation or exceeds the permitted use, you will need to obtain permission directly from the copyright holder.

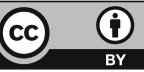

